\title{
Enslavement in the Indian Ocean World: Introducing a Theme
}

\author{
Hans Hägerdal
}

Slavery. The word has, for a modern audience, almost exclusively negative connotations. Only the most outlandish and extremist figures may seem to endorse the idea of ownership over the body and work of another human being. ${ }^{1}$ At a closer look, slavery, in the sense of coerced and unfree labour, is nevertheless highly present in modern societies, even in relatively affluent ones. According to a report from 2014, as many as 35,8 million people around the world live in slave-like conditions, actually more than ever in human history. ${ }^{2}$ Such estimates depend on how one prefers to define "slavery", which is a notoriously difficult term to pinpoint. It is nevertheless clear that patterns of ownership over other humans constitute a recurring theme in recorded history. It is often associated with the classical age of Greece and Rome, and with the trans-Atlantic slave trade in the early-modern era, but in fact slavery appears in most human societies, at one point or another. Joseph C. Miller has rightly pointed out that Western ideas of slavery as a system are insufficient to understand the multiple forms of "slavery" that are found in human cultures. While avoiding a definite definition of the contested "slave" term, he questions the idea of slaving (the acquisition and allocation of coerced labour) as a system, or even a set of systems, and rather characterizes it as a series of strategies coming out of peculiar historical contexts, thus steadily in flux. In Miller's model, slaving has been historically propelled by actors operating from positions of marginality in relation to society leaders merchants, raiders and others who strive to amass social capital and enhance their positions in society. ${ }^{3}$ This global omnipresence makes serious analysis of the dynamics of slaving the more vital and challenging. What factors tend to reduce humans to strongly subservient status, and what are the dynamics of handling and allocating them? How do ideological, religious, social, economic and political factors interplay to maintain slaving systems?

A good way to start is to look at the dynamics evolving in a particular historical region, and this thematic issue comprises four studies detailing slavery in various Indian Ocean contexts. In fact, the Indian Ocean World is interesting as a historical category from several points of view, in spite of its

\footnotetext{
${ }^{1}$ Dick Harrison, Slaveri. En världshistoria om ofrihet. Forntiden till renässansen (Lund: Historiska Media, 2006), 29.

${ }^{2}$ Marcel van der Linden, "Dissecting Coerced Labour", in Marcel van der Linden \& Magaly Rodriguez García (eds), On Coerced Labour: Work and Compulsion after Chattel Slavery (Leiden \& Boston: Brill, 2016), 293-322.

${ }^{3}$ Joseph C. Miller, The Problem of Slavery as History: A Global Approach (New Haven \& London: Yale University Press, 2012).
} 
vast dimensions. While our thinking in historical regions is still often tied to ideas of continents and parts of continents, there is a growing awareness among scholars of the networks crisscrossing the seas, and their importance to explain historical processes in the adjacent lands. The monsoon system and a number of related environmental factors have pushed this vast expanse into certain historical trajectories. ${ }^{4}$ Agricultural production, seaborne access, and consequently trading flows, arise from the seasonal character of the monsoon winds and precipitation and have fostered early connectivities across the ocean. As an ultimate consequence of this, enslaved Africans found their way to India or Southeast Asia, while Balinese and Timorese people could equally well end up toiling on the plantations of the Mascarenes. ${ }^{5}$ The relatively accessible nature of the Indian Ocean sea routes also made for the early intervention of outsiders. Muslim groups settled along the Swahili coast by the ninth century, Indian seafarers made an impact in Southeast Asia since the early centuries of the Christian era, and Europeans established outposts in increasing numbers after c. 1500 . The period and places covered by the four articles in this issue were in particular imprinted by the hegemonic ambitions of European colonial organizations - Portuguese, Dutch, British and others. In all these enterprises, the enslavement and allocation of enslaved people had a large role. In other regions, African and Asian raiders were the more active in acquiring captives through warfare and raiding. Examples of this are the eastern part of what is now Indonesia, Madagascar, and the hinterland of Mozambique; the two last-mentioned are dealt with in the studies of Michael Reidy and Filipa Ribeiro da Silva, where the interesting connections between indigenous and European slaving are also highlighted.

\footnotetext{
${ }^{4}$ Gwyn Campbell, "Introduction: Bondage and the Environment in the Indian Ocean World", in Gwyn Campbell (ed.), Bondage and the Environment in the Indian Ocean World (Cham: Palgrave Macmillan, Springer Nature, 2018), 1-2.

${ }^{5}$ Hans Hägerdal, "At the Margins of the Indian Ocean World: South Asian Migrants and Early Modern Colonialism", in Kristina Myrvold \& Soniya Billore (eds), India: Research on Cultural Encounters and Representations at Linnaeus University (Göteborg \& Stockholm: Makadam, 2017), 180-181.
} 


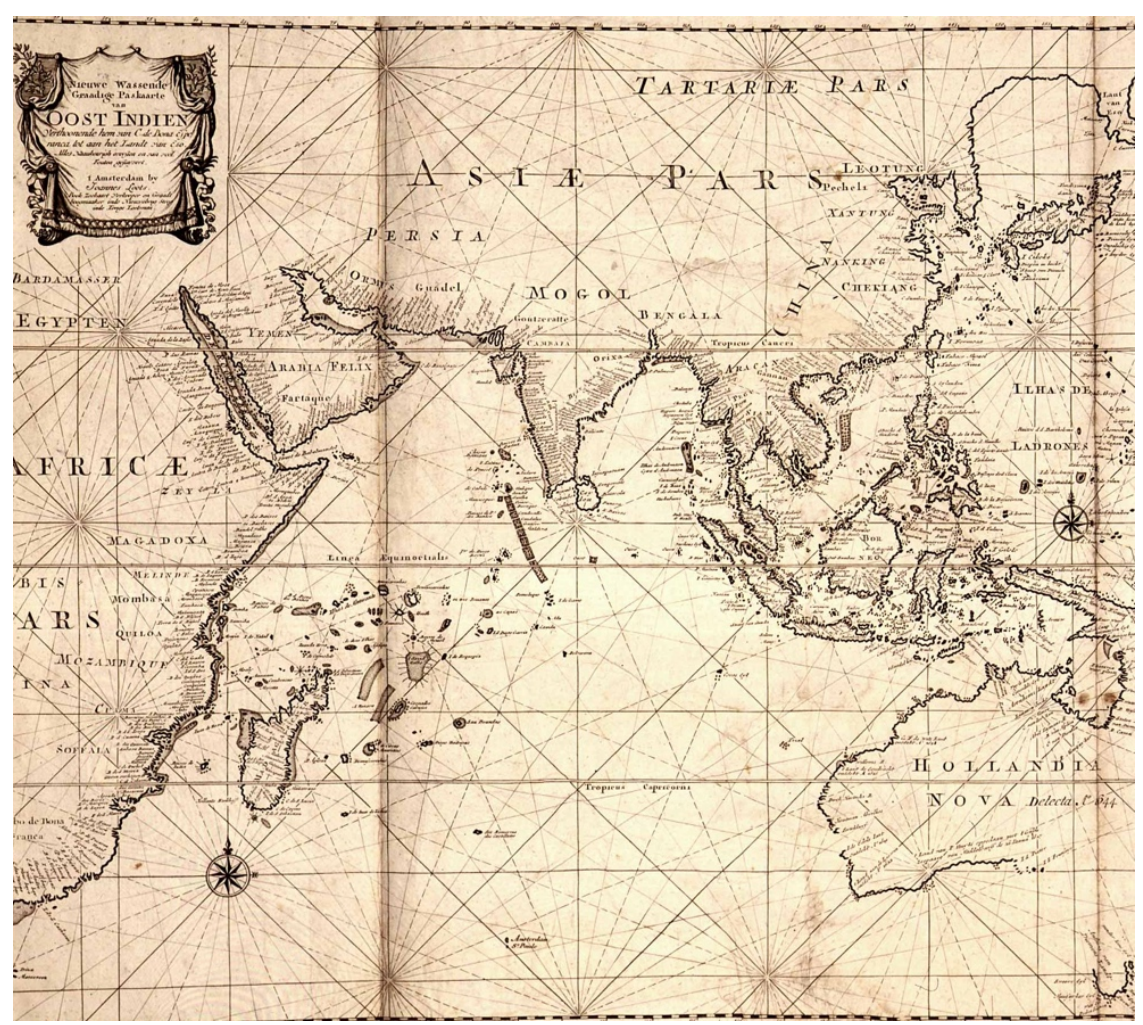

Map 1. The Indian Ocean World. VOC map from about 1700, entitled "Nieuwe Wassende Graadige Paskarte van Oost Indien". Source: Wikimedia Commons, https://sv.wikipedia.org/wiki/Fil:VOC_Octrooigebied_1.jpg.

Then, what was the rationale for this trafficking over the centuries? Already the numbers that can be estimated for the Indian Ocean World indicate that considerable economic interests were at stake. This is connected to demographic structures; in large areas of the Indian Ocean World, labour was scarce, rather than land. ${ }^{6}$ Although the numbers are much more conjectural than for the Atlantic Middle Passage, millions of people from East Africa, South and Southeast Asia were traded over the period 650-1900, often to long-distance destinations. ${ }^{7}$ As apparent from the studies published here, there was a large market for domestic slaves. Often, this was bound up with status issues: the well-to-do in indigenous as well as colonial European households could have hundreds of slaves as a matter of displaying one's own

\footnotetext{
${ }^{6}$ Anthony Reid, Southeast Asia in the Age of Commerce. Volume One: The Lands Below the Wind (New Haven and London: Yale University Press, 1988), 129.

${ }^{7}$ Richard B. Allen, "Human Trafficking in Asia before 1900: A Preliminary Census," International Association for Asian Studies Newsletter, no. 87, October 2020.
} 
importance in society. ${ }^{8}$ But there was also another dimension to it. European settlers founded or took over plantations that produced cash crops such as sugar and spices, notably in the Mascarenes and the Banda Islands. ${ }^{9}$ In their need for a steady supply of manpower, they parallel the infamous West Indian plantations in part. Even they were, however, only a minor part of the picture, since commercial slave-driven plantations were also found in places outside the European sphere, like Zanzibar, Pemba and the Persian Gulf region, producing spices and dates for the global market. ${ }^{10}$

It is important to note that there was not one particular type of slaving regime in the Indian Ocean World, nor do the local terms exactly correspond to the European word "slave" (escravo, slaaf, esclave, etc.). The great variety of forms has been mapped in the works edited by Gwyn Campbell, who has pioneered the study of slavery in the geographical framework of the Indian Ocean. ${ }^{11}$ The free versus unfree distinction made in Roman law is not entirely relevant here. Rather, we are confronted with degrees of un-freedom, where some categories might be akin to what was called serfs in medieval and earlymodern Europe. Typically, the Dutch East India Company (VOC) made no real distinction between slave (slaaf) and serf(lijfeigen) in their writings, and the confused European nomenclature is often misleading. Enslavement could happen in several ways, which was partly reflected in the way "slaves" were treated. According to Anthony Reid, speaking in a Southeast Asian context, debts were the most prominent reason for the loss of personal freedom, though it was often understood that this condition only lasted as long as the debt remained unpaid. ${ }^{12}$ Other slaves inherited their status, or were sentenced to slavery as the result of criminal acts or witchcraft. An important source was political unrest: capture in warfare or through slave raiding. While the regions adjacent to the Indian Ocean had several strong states in the pre-colonial era, there was also a variety of petty kingdoms, collapsed realms, and stateless areas with no organization above village level. Political fragmentation led to raiding, both internally and by outsiders, and the consequent capture of manpower. ${ }^{13}$ Religious affiliation also made a difference: for Christians as well as Muslims, enslavement of co-religionists was formally discouraged. Reality was often very different from theory, however, as shown by James

\footnotetext{
${ }^{8}$ Hans Hägerdal, Lords of the Land, Lords of the Sea: Conflict and Adaptation in Early Colonial Timor 1600-1800 (Leiden: KITLV Press, 2012), 275.

${ }^{9}$ Markus Vink, "'The World's Oldest Trade.' Dutch Slavery and the Slave Trade in the Indian Ocean in the Seventeenth Century,' Journal of World History 14, no. 7 (2003): 13177.

10 Titas Chakraborty and Matthias van Rossum, "Slave Trade and Slavery in Asia - New

Perspectives", Journal of Social History 54, no. 1 (2020).

${ }^{11}$ See especially Gwyn Campbell (ed.), The Strucure of Slavery in Indian Ocean Africa and Asia (London: Frank Cass, 2004).

${ }^{12}$ Reid, Southeast Asia in the Age of Commerce, 131.

${ }^{13}$ An illustrative case is discussed by Rodney Needham, Sumba and the Slave Trade (Monash: Centre for Southeast Asian Studies, Working Papers, 31).
} 
Warren in his classic work The Sulu Zone. ${ }^{14}$ The different sources of enslavement often made for a variety of terms for coerced labour within one and the same society. In West Sumbawa in present-day Indonesia, for example, there were three categories: the tau marisi who were similar to serfs, the budak pusaka who were enslaved due to internal conflicts and debts, and the $a b d i$ who came from the outside and had few rights. ${ }^{15}$

One may also note the connections between the slave systems. In post1980 research about slavery, a rough distinction is often made between open and closed forms. ${ }^{\mathbf{1 6}}$ Open types of slavery are characterized by a social bond between the slave and his or her owner. The slave tends to be a member of the household, and might be integrated in a family. Descendants of slaves acquired via capture, purchase or debt may be assimilated in the dominant group after a few generations, which is facilitated if there are no great physical differences. ${ }^{17}$ One may take the example of Timor, where societies were strongly hierarchical but at the same time based on small lineage-based settlements where a category of bonded labour (atan in Tetun language, ate in Dawan, translated in Portuguese and Dutch reports as escravos, slaven, slaves) worked the land. They were not clan property but rather served individual households, generally the elite. ${ }^{18}$ At least in parts of Timor, these people could not be sold. Under certain circumstances a slave could be adopted and inherit the clan name of his master. ${ }^{19}$ Ethnographic research from areas that came under colonial surveillance at a late stage points out the fatherchild relationship that evolved as an atan was internalized in a household. ${ }^{\mathbf{2 0}}$ A Portuguese survey of customary right from 1869 argued that "the slaves in Timor as those in Arabia, are treated like persons in the family; they are not objects like the case in Roman law and in the exploitation in North and South America". ${ }^{21}$ This would appear to concur with the common if debatable notion that slavery in the Indian Ocean World was "mild" in comparison with the Atlantic type. ${ }^{\mathbf{2 2}}$

\footnotetext{
${ }^{14}$ James Francis Warren, The Sulu Zone: The Dynamics of External Trade, Slavery, and Ethnicity in the Transformation of a Southeast Asian Maritime State (Singapore: NUS Press, 2007).

${ }^{15}$ W.G. van der Wolk, Memorie Soembawa, 1941. H 1087, KITLV Archive, Leiden. 16 Gwyn Campbell, "Introduction: Slavery and Other Forms of Unfree Labour in the Indian Ocean World", in Campbell (ed), The Structure of Slavery, xv-xviii.

17 Anthony Reid, "'Closed' and 'Open' Slave Systems in Pre-Colonial Southeast Asia", in Anthony Reid (ed.), Slavery, Bondage and Dependency in Southeast Asia (St Lucia, London and New York: University of Queensland Press, 1983), 156.

18 Alexander Un Usfinit, Maubes Insana (Yogyakarta: Kanisius, 2008), 81; Herman Joseph Seran, Ema Tetun (Kupang: Gita Kasih, 2007), 120.

19 Affonso de Castro, As possessões portuguezas na Oceania (Lisboa: Imprensa Nacional, 1867), 319-320.

20 B.A.G. Vroklage, Ethnographie der Belu in Zentral-Timor, Erster Teil (Leiden: Brill, 1953), 550; Seran, Ema Tetun, 120-121.

21 Adatrechtbundels XXXIX, Gemengd ('s-Gravenhage: M. Nijhoff, 1939), 470.

22 Campbell, "Introduction: Slavery" xxiii.
} 
On the other end of the binary is the closed type where a slave is and remains an essential outsider, in Indian Ocean contexts often in relatively static and labour-intensive societies. ${ }^{23}$ In European contexts, they are property in the sense that they can be bought and sold, and there is a legal free-unfree distinction that is often underlined by physical differences. This is associated with slave markets and transports of human cargo over great distances. The open-closed distinction might be useful as a binary of ideal types in the Weberian sense; however, as detailed studies have proliferated in recent decades, a more complex picture of Asian slave-keeping societies has emerged. Local systems of bondage and slavery that tied people to a master, household and work task, existed both alongside and in interaction with systems where slavery was commodified and often inter-regional. ${ }^{24}$ As noted by Peter Boomgaard when speaking of Indonesia, rather than finding a general theory of the widespread enslavement, one may look at the hazards of pre-modern society, which made for a high degree of uncertainty in daily life: war, raids, gambling, debts, and so on. ${ }^{25}$

There is no express prohibition against ownership of humans in either world religions or pre-modern political systems, and abolition came lately to the Indian Ocean World. The widespread practice of slaving among European, African and Asian groups made abolitionist activity problematic. From a legal point of view, slavery was ended by the European colonial powers in the course of the nineteenth century, but it was a slow demise. Britain set the agenda by abolishing the institution in the territories of the East India Company in 1843, and the other powers followed suit in the next decades. ${ }^{26}$ However, as discussed by Akanksha Singh in this issue, coerced labour survived in various forms, and does so until this day. In indirectly ruled territories, slavery lasted into the twentieth century, and the same goes for countries that survived formal colonization - Yemen and Saudi Arabia formally abolished slavery as late as $1962 .^{27}$

The essays in this issue of HumaNetten provide fascinating cases of all this. They all analyze places where European colonialism and shipping had made inroads: South Africa-Madagascar, Sri Lanka, Mozambique, and India. They demonstrate how European traders, administrators and settlers interacted with local economic and social structures, often making for an element of hybridity in the colonial contact zones. In this, they continue the

\footnotetext{
${ }^{23}$ Reid, "'Closed' and 'Open' Slave Systems", 156, 161.

${ }^{24}$ Alexander Geelen, Bram van den Hout, Merve Tosun, Mike de Windt and Matthias van Rossum, "On the Run: Runaway Slaves and Their Social Networks in Eighteenth-Century Cochin”, Journal of Social History 54, no. 1 (2020): 66-87.

25 Peter Boomgaard, "Human Capital, Slavery and Low Rates of Economic and Population Growth in Indonesia, 1600-1910", Slavery and Abolition 24 (2003): 90.

${ }^{26}$ Dick Harrison, Slaveri. En världshistoria om ofrihet. Från 1800 till nutid (Lund: Historiska Media, 2008), 538.

${ }^{27} \mathrm{BBC}$, Slavery in Islam, https://www.bbc.co.uk/religion/religions/islam/history/slavery_1.shtml (accessed 13-92021).
} 
path of research begun by scholars such as Gwyn Campbell, Richard Allen and Matthias van Rossum, which has seen a steady outpour of books and articles in the last few decades. ${ }^{28}$ This ongoing research will no doubt remedy the two "curses" associated with the field. The "curse of the Atlantic" has made many people watch slaving around the world through the lens of transAtlantic slave trade, downplaying or disregarding the climatic, cultural and economic factors that led Indian Ocean slaving into partly different trajectories. Secondly, scholars afflicted by "the curse of the particular" have produced deep studies of geographically delimited slave economies without seeing them in larger and comparative contexts. ${ }^{29}$ This is currently being remedied by scholarly networks such as ESTA (Exploring Slave Trade in Asia) which organize conferences and workshops and include Asian, African and Western scholars.

The four contributions to the issue have been arranged in a rough chronological order. The first article by Michael Charles Reidy studies part of the extensive slave trade in the south-western part of the Indian Ocean World in the early-modern era. Although a number of historians have reconstructed aspects of these trades over the last forty-five years, our knowledge about this traffic remains far from complete, a historiographical shortcoming which Reidy addresses. He draws on a range of archival sources, especially the instructions issued to ship captains and trade journals, to expand our current understanding of the dynamics of European, and identify the formation of Dutch slave trading policy on the island.

Secondly, Lodewijk Wagenaar takes a look at the workings of the colonial contact zones. In this study, he examines how slavery and slaves were viewed in late-eighteenth- and early nineteenth-century Ceylon or Sri Lanka. The island had been partly colonized for hundreds of years, fostering a hybrid society in the coastal towns. The era studied by Wagenaar witnessed the dramatic transition from Dutch to British rule. The author's investigation makes use of hitherto unused sources to explore how attitudes about bonded labor changed during an era of increasing abolitionist activity in the Indian Ocean, changes that involved the complex interplay between indigenous and European ideas about forced labor.

The third contribution by Filipa Ribeiro da Silva takes us back to Africa. Similar to Ceylon, coastal Mozambique has a long history of colonial settlement which engendered routines of co-habitation between Portuguese, Africans and external Muslims settlers over the centuries. Ribeiro da Silva draws on the demographic data provided by hitherto unused household and estate surveys to explore the dynamics of enslavement in three nineteenth-

\footnotetext{
${ }^{28}$ See, for instance: Gwyn Campbell, ed., Bondage and the Environment in the Indian Ocean World (Cham: Palgrave Macmillan, Springer Nature, 2018); Richard B. Allen, European Slave Trading in the Indian Ocean, 1500-1850 (Athens: Ohio University Press, 2015); Matthias van Rossum, Kleurrijke tragiek: de geschiedenis van slavernij in Azië onder de VOC (Hilversum: Uitgeverij Verloren).

${ }^{29}$ Cf. Allen, European Slave Trading in the Indian Ocean.
} 
century Mozambican towns. The patterns are amply illustrated by a set of statistical tables. These data lead her to argue that different forms of slavery co-existed in the studied communities.

Lastly, Akanksha Narayan Singh reassesses the type of slavery that existed in nineteenth-century British India and describes how slavery was formally abolished in the East India Company possessions in 1843. As she observes, the legal abolition of slavery did not, however, bring an end to such coerced labor, and slavery in effect continued to exist in various forms and places until well into the twentieth century. In so doing, she questions the conventions inherent in most discussions about slavery in India such as the belief that it was relatively mild and paternalistic and restricted largely to South India.

The four articles published here began as papers presented at a lively workshop in Kalmar, Sweden, in September 2017, also entitled "Enslavement in the Indian Ocean World". ${ }^{30}$ Our thoughts go to the late Joseph C. Miller, the great synthesizer of global slavery studies, who offered insightful comments to the papers discussed at the workshop. Publication of the issue has been enabled through a generous contribution by the Linnaeus University Center for Concurrences in Colonial and Postcolonial Studies (Concurrences, for short), a vibrant interdisciplinary milieu with an interest in the power configurations and discriminatory practices that have shaped the modern world.

\section{Bibliography}

Adatrechtbundels XXXIX, Gemengd ('s-Gravenhage: M. Nijhoff, 1939).

Allen, Richard B., European Slave Trading in the Indian Ocean, 1500-1850 (Athens: Ohio University Press, 2015).

Allen, Richard B., "Human Trafficking in Asia before 1900: A Preliminary Census," International Association for Asian Studies Newsletter, no. 87, October 2020.

BBC, Slavery in Islam, https://www.bbc.co.uk/religion/religions/islam/history/ slavery_1.shtml (accessed 13-9-2021).

Boomgaard, Peter, "Human Capital, Slavery and Low Rates of Economic and Population Growth in Indonesia, 1600-1910", Slavery and Abolition 24 (2003): 83-96.

Campbell, Gwyn (ed.), The Strucure of Slavery in Indian Ocean Africa and Asia (London: Frank Cass, 2004).

Campbell, Gwyn (ed.), Bondage and the Environment in the Indian Ocean World (Cham: Palgrave Macmillan, Springer Nature, 2018).

Castro, Affonso de, As possessões portuguezas na Oceania (Lisboa: Imprensa Nacional, 1867).

\footnotetext{
${ }^{30}$ For this workshop, see also Emilie Wellfelt, "Meddelanden: Enslavement in the Indian Ocean World, Kalmar, 8-9 september 2017", Historisk tidskrift 138, no. 1 (2018): 176-177. We are grateful to the Crafoord Foundation, Lund, that contributed to the workshop through a grant. Thanks also go to two anonymous reviewers who provided valuable feedback on the four contributions.
} 
Chakraborty, Titas, and Matthias van Rossum, "Slave Trade and Slavery in Asia - New Perspectives", Journal of Social History 54, no. 1 (2020): 1-14.

Geelen, Alexander, Bram van den Hout, Merve Tosun, Mike de Windt and Matthias van Rossum, "On the Run: Runaway Slaves and Their Social Networks in Eighteenth-Century Cochin”, Journal of Social History 54, no. 1 (2020): 66-87.

Hägerdal, Hans, Lords of the Land, Lords of the Sea: Conflict and Adaptation in Early Colonial Timor 1600-1800 (Leiden: KITLV Press, 2012).

Hägerdal, Hans, "At the Margins of the Indian Ocean World: South Asian Migrants and Early Modern Colonialism", in Kristina Myrvold \& Soniya Billore (eds), India: Research on Cultural Encounters and Representations at Linnaeus University (Göteborg \& Stockholm: Makadam, 2017), 162-187.

Harrison, Dick, Slaveri. En världshistoria om ofrihet. Forntiden till renässansen (Lund: Historiska Media, 2006).

Harrison, Dick, Slaveri. En världshistoria om ofrihet. Från 1800 till nutid (Lund: Historiska Media, 2008).

Linden, Marcel van der, "Dissecting Coerced Labour", in Marcel van der Linden \& Magaly Rodriguez García (eds), On Coerced Labour: Work and Compulsion after Chattel Slavery (Leiden \& Boston: Brill, 2016), 293322.

Miller, Joseph C., The Problem of Slavery as History: A Global Approach (New Haven \& London: Yale University Press, 2012).

Needham, Rodney, Sumba and the Slave Trade (Monash: Centre for Southeast Asian Studies, Working Papers, 31).

Reid, Anthony, "'Closed' and 'Open' Slave Systems in Pre-Colonial Southeast Asia", in Anthony Reid (ed.), Slavery, Bondage and Dependency in Southeast Asia (St Lucia, London and New York: University of Queensland Press, 1983), 156-181.

Reid, Anthony, Southeast Asia in the Age of Commerce. Volume One: The Lands Below the Wind (New Haven and London: Yale University Press, 1988).

Rossum, Matthias van, Kleurrijke tragiek: de geschiedenis van slavernij in Azië onder de VOC (Hilversum: Uitgeverij Verloren).

Seran, Herman Joseph, Ema Tetun (Kupang: Gita Kasih, 2007).

Usfinit, Alexander Un, Maubes Insana (Yogyakarta: Kanisius, 2008).

Vink, Markus, “'The World's Oldest Trade.' Dutch Slavery and the Slave Trade in the Indian Ocean in the Seventeenth Century," Journal of World History 14, no. 7 (2003): 131-177.

Vroklage, B.A.G., Ethnographie der Belu in Zentral-Timor, Erster Teil (Leiden: Brill, 1953).

Warren, James Francis, The Sulu Zone: The Dynamics of External Trade, Slavery, and Ethnicity in the Transformation of a Southeast Asian Maritime State (Singapore: NUS Press, 2007).

Wellfelt, Emilie, "Meddelanden: Enslavement in the Indian Ocean World, Kalmar, 8-9 september 2017", Historisk tidskrift 138, no. 1 (2018): 176177. 
Wolk, W.G. van der, Memorie Soembawa, 1941. H 1087, KITLV Archive, Leiden. 